\title{
Granulosicoccus coccoides sp. nov., isolated from leaves of seagrass (Zostera marina)
}

\author{
Valerie V. Kurilenko, ${ }^{1}$ Richard Christen, ${ }^{2}$ Natalia V. Zhukova, ${ }^{3}$ Nataliya I. \\ Kalinovskaya, ${ }^{1}$ Valery V. Mikhailov, ${ }^{1}$ Russell J. Crawford ${ }^{4}$ \\ and Elena P. Ivanova ${ }^{4}$ \\ ${ }^{1}$ Pacific Institute of Bioorganic Chemistry of the Far-Eastern Branch of the Russian Academy of \\ Sciences, 690022 Vladivostok, Pr. 100 Let Vladivostoku 159, Russian Federation \\ ${ }^{2}$ Université de Nice Sophia-Antipolis and Centre National de la Recherche Scientifique (CNRS) \\ UMR 6543, Centre de Biochimie, Parc Valrose, F 06142 Nice, France \\ ${ }^{3}$ Institute of Marine Biology of the Far-Eastern Branch of the Russian Academy of Sciences, \\ 690041 Vladivostok, Russian Federation \\ ${ }^{4}$ Swinburne University of Technology, PO Box 218, Hawthorn, Vic 3122, Australia
}

Correspondence

Elena P. Ivanova

eivanova@swin.edu.au
The genus Granulosicoccus, with the single species Granulosicoccus antarcticus, was described in 2007 as a member of the newly proposed family Granulosicoccaceae (Lee et al., 2007) of the order Chromatiales (Imhoff, 2005).

In this study, we report the characterization of a novel bacterium of the genus Granulosicoccus, isolated in July 1998 from leaves of the seagrass Zostera marina. The seagrass was collected in Troitza Bay of the Gulf of Peter the Great (Kurilenko et al., 2007). A strain, $\mathrm{Z} 271^{\mathrm{T}}$, was isolated from an individual colony grown for 7 days at $28{ }^{\circ} \mathrm{C}$ on a medium (designated 'Medium A') containing: $0.2 \%(\mathrm{w} / \mathrm{v})$ Bacto peptone (Oxoid), $0.2 \%(\mathrm{w} / \mathrm{v})$ casein hydrolysate (Merck), $0.2 \%$ (w/v) Bacto yeast extract

Abbreviation: FAMEs, fatty acid methyl esters.

The GenBank/EMBL/DDBJ accession number for the $16 \mathrm{~S}$ rRNA gene sequence of strain $Z 271^{\top}$ is FJ535355.

Transmission electron micrographs of cells of strain $Z 271^{\top}$ and an extended phylogenetic tree are available as supplementary figures with the online version of this paper. A supplementary table detailing the cellular fatty acid composition of the novel strain is also available.
(Oxoid), $0.1 \%(\mathrm{w} / \mathrm{v})$ glucose, $0.02 \%(\mathrm{w} / \mathrm{v}) \quad \mathrm{KH}_{2} \mathrm{PO}_{4}$, $0.005 \%(\mathrm{w} / \mathrm{v}) \quad \mathrm{MgSO}_{4} .7 \mathrm{H}_{2} \mathrm{O}, 1.5 \%$ (w/v) Bacto agar (Oxoid), $50 \%(\mathrm{v} / \mathrm{v})$ natural seawater and $50 \%(\mathrm{v} / \mathrm{v})$ distilled water at $\mathrm{pH}$ 7.8. The isolation (by the replicaplating method) and purification procedures have been described elsewhere (Ivanova et al., 1996). The strain was stored at $-80{ }^{\circ} \mathrm{C}$ in marine broth 2216 (MB, Oxoid) supplemented with $20 \%(\mathrm{v} / \mathrm{v})$ glycerol.

The following physiological and biochemical properties were determined by methods described by Smibert \& Krieg (1994): oxidation/fermentation of glucose, denitrification (Azegami et al., 1987), oxidase and catalase activity, gelatin liquefaction, arginine dihydrolase, lysine decarboxylase, ornithine decarboxylase, sodium requirement $[0,0.5,1,3$, $5,8,10,12 \%(\mathrm{w} / \mathrm{v}) \mathrm{NaCl}$ ], indole and $\mathrm{H}_{2} \mathrm{~S}$ production and the ability to hydrolyse starch, Tween 80 and casein. The growth of the novel strain at different temperatures was determined in MB and on plates of Medium A after 24$72 \mathrm{~h}$ at $2,4,6,29,30,35$ and $37^{\circ} \mathrm{C}$. Biolog GN test kits were also used to examine the primary oxidation of 95 carbon compounds as described elsewhere (Ivanova et al., 
1998). Other biochemical tests were carried out with API 2NE and API ZYM strips (bioMérieux). To enable the isolation and characterization of bacteriochlorophyll $a$, strain $\mathrm{Z} 271^{\mathrm{T}}$ was grown at $28{ }^{\circ} \mathrm{C}$ on marine agar 2216 (MA, Oxoid) over $48 \mathrm{~h}$ and the bacterial mass was collected from five Petri plates as described elsewhere (Ivanova et al., 2004, 2005a). Cell morphology was examined by transmission electron microscopy (Libra 120; Carl Zeiss) using cells from 1, 4, and 8 day cultures on MA at $28{ }^{\circ} \mathrm{C}$. A drop of particle-free (autoclaved and ultracentrifuged) distilled water was placed on the growth of a $24 \mathrm{~h}$-culture. A $30 \mu \mathrm{l}$ sample of the resulting bacterial suspension was applied to carbon- and Formvar-coated 400-mesh copper grids. A drop of $1.25 \%(\mathrm{w} / \mathrm{v})$ uranyl acetate was added and the bacteria were allowed to adhere for $1 \mathrm{~min}$ at room temperature. Superfluous liquid was gently removed by using a piece of filter paper.

Phenotypic analyses showed that strain $\mathrm{Z} 271^{\mathrm{T}}$ was Gramnegative, strictly aerobic, oxidase- and catalase-positive, formed buds, produced polyhydroxybutyrate granules as storage material (See Supplementary Fig. S1 in IJSEM Online), produced $\mathrm{H}_{2} \mathrm{~S}$ and indole and did not show a tendency towards denitrification. The morphological and physiological properties of strain $\mathrm{Z} 271^{\mathrm{T}}$ are given in Table 1 and in the species description.

To determine the phospholipid and fatty acid contents, cell biomass of strain $\mathrm{Z} 271^{\mathrm{T}}$ and G. antarcticus IMCC $3135^{\mathrm{T}}$ was harvested from agar plates after cultivation for $48 \mathrm{~h}$ on MA at $28{ }^{\circ} \mathrm{C}$. Lipids were extracted according to the method described by Bligh \& Dyer (1959). Polar lipids were separated and identified as previously described (Ivanova et al., 2005b). The lipids were treated with $5 \%$ $\mathrm{HCl}$ in methanol at $80{ }^{\circ} \mathrm{C}$ for $180 \mathrm{~min}$ to produce fatty acid methyl esters (FAMEs) (Christie, 1982). FAMEs were analysed by FID-GC (GC-17; Shimadzu) with a fused silica capillary column $(30 \mathrm{~m} \times 0.25 \mathrm{~mm})$ coated with Supelcowax 10 at $210{ }^{\circ} \mathrm{C}$. Helium was used as the carrier gas. FAMEs were identified by comparing the retention times with those of authentic standards and using equivalent chain-length measurements. To ensure correct identification, FAMEs were analysed by GC-MS (GCMS0QP5050A; Shimadzu) fitted with an MDN-5S capillary column $(30 \mathrm{~m} \times 0.25 \mathrm{~mm})$. The column was programmed to hold the temperature at $170{ }^{\circ} \mathrm{C}$ for $1 \mathrm{~min}$, increase it to $240{ }^{\circ} \mathrm{C}$ at $2{ }^{\circ} \mathrm{C} \mathrm{min}^{-1}$ and to then hold it at $240{ }^{\circ} \mathrm{C}$ for $20 \mathrm{~min}$. The temperature of the injector and detector was $250{ }^{\circ} \mathrm{C}$. Phosphatidylethanolamine $(36.9 \%)$ and phosphatidylglycerol (63.1\%) were found to be the major constituents of the phospholipids. Traces of diphosphatidylglycerol were also detected, however no glycophospholipids were detected. The major fatty acids formed by strain $\mathrm{Z} 271^{\mathrm{T}}$ were $\mathrm{C}_{18: 1} \omega 7 c(43.7 \%)$, $\mathrm{C}_{16: 1} \omega 7 c(31.1 \%)$ and $\mathrm{C}_{16: 0}(16.8 \%)$ (see Supplementary Table S1 in IJSEM Online). The isoprenoid quinone composition was characterized by HPLC-MS (1200L; Varian) using a reverse phase type Varian Omnisphere 3 C18 column $(20 \mathrm{~cm} \times 2 \mathrm{~mm})$ and acetonitrile as the mobile phase at a flow rate of $0.5 \mathrm{ml} \mathrm{min}^{-1}$. The column was held at a temperature of $55{ }^{\circ} \mathrm{C}$. Menaquinones were detected by UV-visible analysis at a wavelength of $270 \mathrm{~nm}$.

The 16S rRNA gene sequence was amplified and sequenced by the Australian Genome Research Facility (AGRF) Laboratories (Brisbane, Australia). The 16S rRNA gene sequence (GenBank accession no. FJ535355) of strain $\mathrm{Z} 271^{\mathrm{T}}$ was analysed by BLAST against a database of cultured species (http://bioinfo.unice.fr/blast) and the EzTaxon database of bacterial type strains (http://147.47.212.35:8080) in order to retrieve the 80 most similar sequences. These sequences were then aligned with CLUSTAL W2 (Larkin et al., 2007). Alignments were then manually checked with

Table 1. Characteristics that differentiate strain $Z 271^{\top}$ and $G$. antarcticus IMCC $3135^{\top}$

Strains: $1, \mathrm{Z} 271^{\mathrm{T}} ; 2$, G. antarcticus IMCC $3135^{\mathrm{T}}$. Both species are catalase- and oxidase-positive, coccoid cells motile by means of tuft flagella. The $\mathrm{NaCl}$ range for growth is between $0.5 \%$ and $5 \%$. Both strains accumulate polyhydroxybutyrate and do not produce bacteriochlorophyll $a$ or pigments. +, Positive; -, negative; $\mathrm{w}$, weakly positive.

\begin{tabular}{|c|c|c|}
\hline Characteristic & 1 & 2 \\
\hline Bud formation & + & - \\
\hline Temperature optimum $\left({ }^{\circ} \mathrm{C}\right)$ & 25 & 20 \\
\hline $\mathrm{NaCl}$ optimum $(\%, \mathrm{w} / \mathrm{v})$ & 2.5 & 2.0 \\
\hline \multicolumn{3}{|l|}{ Hydrolysis of: } \\
\hline Alkaline phosphatase & - & + \\
\hline Lipase $(\mathrm{C} 14)$ & + & - \\
\hline \multicolumn{3}{|l|}{ Assimilation of: } \\
\hline L-Fructose, L-proline, L-threonine, putrescine, 2-aminoethanol, DL- $\alpha$-glycerol phosphate & - & + \\
\hline $\begin{array}{l}\alpha \text {-Cyclodextrin, } \beta \text {-cyclodextrin, dextrin, glycogen, inulin, mannan, L-arabinose, D-arabitol, cellobiose, D-mannitol, D-ribose, } \\
\text { sucrose, D-xylose, acetic acid, inosine, fructose 6-phosphate, glucose 1-phosphate, glucose 6-phosphate }\end{array}$ & + & - \\
\hline DNA G $+\mathrm{C}$ content $(\mathrm{mol} \%)$ & 60.2 & 57.5 \\
\hline
\end{tabular}


SEAVIEW (Galtier et al., 1996) and domains common to all sequences were used to derive an initial phylogenetic tree using the most recent version of SEAVIEW (see Supplementary Fig. S2 in IJSEM Online). This phylogenetic tree enabled the new strain to be identified as most closely related to the genus Granulosicoccus.

Alignments were checked again and a full phylogenetic analysis was undertaken using the neighbour-joining (BIONJ) and maximum-likelihood algorithms, excluding positions containing indels. For the neighbour-joining analysis, a distance matrix was calculated using the Kimura twoparameter correction. Bootstraps were performed using 1000 replications. BIONJ was used according to the method described by Gascuel (1997) and maximum-likelihood was determined using PhyML (Guindon \& Gascuel, 2003). The phylogenetic trees were drawn using TreeDyn (Chevenet et al., 2006) or SEAVIEW. The new strain formed a very robust cluster (confirmed by all methods) only with $G$. antarcticus IMCC $3135^{\mathrm{T}}$ (100\% bootstrap), showing 18 differences over 1480 nt. The 16S rRNA gene sequence similarity between strain $\mathrm{Z} 271^{\mathrm{T}}$ and G. antarcticus was $98.8 \%$ and the novel strain was thus identified as a member of the genus Granulosicoccus (Fig. 1).

DNA was isolated from the new strain according to the method described by Marmur (1961). The G $+C$ content of the DNA was determined using the thermal denaturation method of Marmur \& Doty (1962). The G + C content of strain $\mathrm{Z} 271^{\mathrm{T}}$ was $60.2 \pm 0.5 \mathrm{~mol} \%$. DNA-DNA hybridization was performed spectrophotometrically as described by De Ley et al. (1970). Strain G. antarcticus IMCC $3135^{\mathrm{T}}$ was kindly provided by Dr Jang-Cheon Cho and Dr Lee Kiyoung. DNA from strain $\mathrm{Z} 271^{\mathrm{T}}$ showed $35 \%$ DNA-DNA hybridization with $G$. antarcticus IMCC $3135^{\mathrm{T}}$. This value was far lower than $70 \%$, which is the cut-off value recommended for the definition of a genomic species (Wayne et al., 1987), and clearly indicated that strain $\mathrm{Z} 271^{\mathrm{T}}$ represents a genomic species that is separate from G. antarcticus IMCC $3135^{\mathrm{T}}$.

In summary, strain $\mathrm{Z} 271^{\mathrm{T}}$ could be easily distinguished from G. antarcticus IMCC $3135^{\mathrm{T}}$ by a number of phenotypic traits. The two strains showed distinct phenotypic profiles as regards their metabolic activity as determined with the API ZYM system and in the assimilation of carbon substrates with Biolog GN microplates (Table 1). In addition, strain $\mathrm{Z} 271^{\mathrm{T}}$ could be distinguished by its particular cell morphology (bud formation), its optimal temperature for growth and the different proportions of major fatty acids, e.g. $\mathrm{C}_{18: 1} \omega 7 c$ and $\mathrm{C}_{16: 0}$. Thus, on the basis of characteristic phenotypic, chemotaxonomic and well-confirmed phylogenetic evidence, strain $\mathrm{Z} 271^{\mathrm{T}}$ represents a novel species of the genus Granulosicoccus for which the name Granulosicoccus coccoides sp. nov. is proposed.

\section{Description of Granulosicoccus coccoides sp. nov.}

Granulosicoccus coccoides [coc.co'i.des, N.L. n. coccus (from Gr. n. kokkos) grain, seed; L. suff. -oides (from Gr. suff. eides, from Gr. n. eidos that which is seen, form, shape, figure) resembling, similar; N.L. masc. adj. coccoides similar to a round, ball-shaped cell morphology].

Round-shaped cells, single and about $1 \mu \mathrm{m}$ in diameter. Gram-negative. Motile by means of tuft flagella, forms

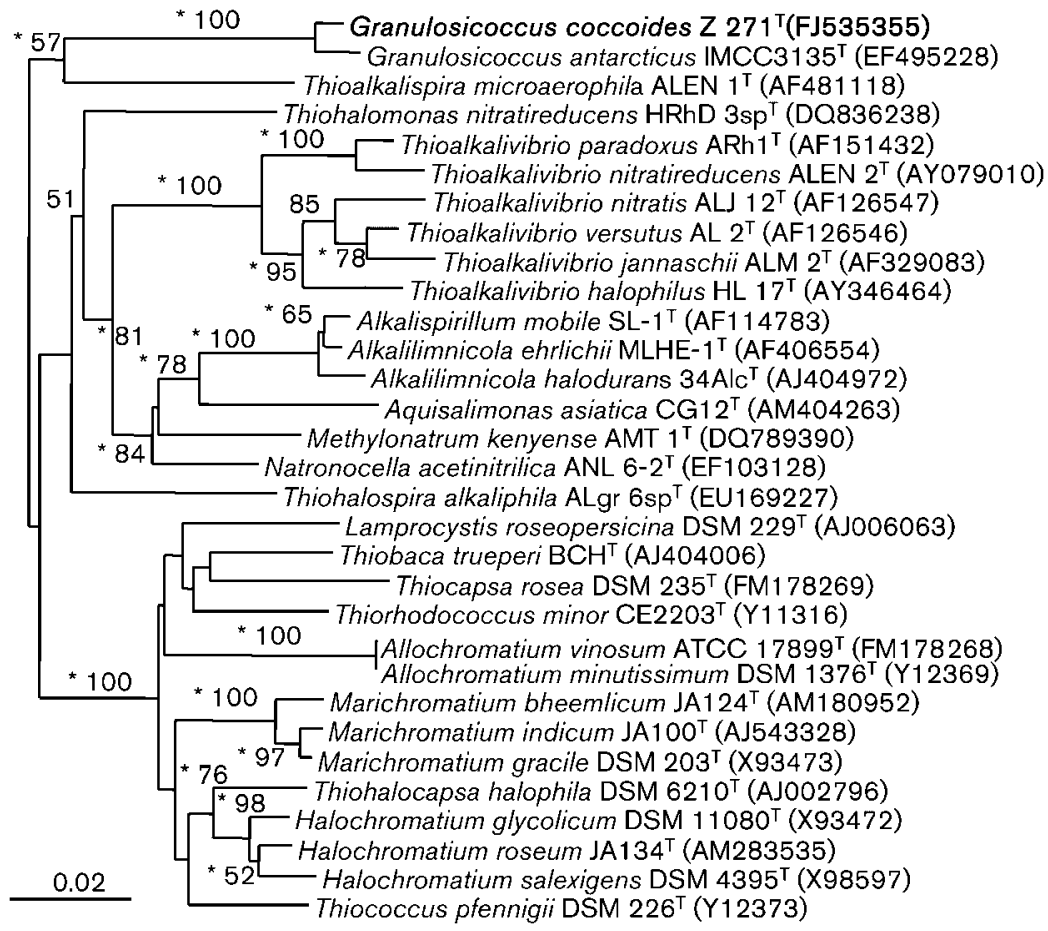

Fig. 1. Phylogenetic position of strain $Z 271^{\top}$ according to $16 \mathrm{~S}$ rRNA gene sequence analysis. The tree is an extract of a larger phylogenetic tree obtained after a distance analysis (See Supplementary Fig. S2). Bootstrap percentages (1000 replications) are indicated for branches when greater than $50 \%$. Asterisks indicate that branches were also retrieved using a maximum-likelihood analysis. Bar, 0.02 substitutions per site. 
buds. Aerobic. Chemorganotrophic with respiratory metabolism. Colonies are uniformly round, $0.5-1 \mathrm{~mm}$ in diameter, regular and convex on MA or Medium A. Does not form endospores. Forms polyhydroxybutyrate granules. Oxidase- and catalase-positive. Requires $\mathrm{Na}^{+}$ions or seawater for growth. Growth occurs in media with $0.5-5 \%$ $(\mathrm{w} / \mathrm{v}) \mathrm{NaCl}$. Temperature for growth ranges from 5 to $28{ }^{\circ} \mathrm{C}$. No growth is detected at $35{ }^{\circ} \mathrm{C}$. The $\mathrm{pH}$ range for growth is 6.0-10.0, with an optimum at 7.5-8.0. Negative for indole, arginine dihydrolase, lysine decarboxylase, ornithine decarboxylase and $\mathrm{H}_{2} \mathrm{~S}$ production. Decomposes Tweens 20, 40 and 80 , weakly decomposes gelatin. Utilizes the following carbon sources (Biolog): $\alpha$-cyclodextrin, $\beta$-cyclodextrin, dextrin, glycogen, inulin, mannan, Tween 40, Tween 80, $N$-acetyl-D-glucosamine, $N$-acetyl-Dmannosamine, L-arabinose, D-arabitol, arbutin, cellobiose, D-fructose, L-fucose, D-galactose, D-galacturonic acid, gentiobiose, D-gluconic acid, $\alpha$-D-glucose, myo-inositol, $\alpha$-D-lactose, lactulose, maltose, maltotriose, D-mannitol, Dmannose, D-ribose, sucrose, D-xylose, acetic acid, $\beta$ hydroxybutyric acid, $\alpha$-ketovaleric acid, lactamide, D-lactic acid methyl ester, L-lactic acid, mono-methyl succinate, propionic acid, pyruvic acid, succinamic acid, succinic acid, L-serine, inosine, fructose 6-phosphate, glucose 1phosphate, glucose 6-phosphate. According to API ZYM strips, produces esterase (C4), esterase lipase (C8), lipase (C14), acid phosphatase, naphthol-AS-BI-phosphohydrolase, $N$-acetyl- $\beta$-glucosaminidase. According to API $20 \mathrm{NE}$ strips, produces $\beta$-glucosidase and para-nitrophenyl- $\beta$-Dgalactopyranosidase. The predominant phospholipids are phosphatidylethanolamine $(36.9 \%)$ and phosphatidylglycerol $(63.1 \%)$. The main cellular fatty acids are $\mathrm{C}_{18: 1} \omega 7 c$ $(43.7 \%), \mathrm{C}_{16: 1} \omega 7 c(31.1 \%)$ and $\mathrm{C}_{16: 0}(16.8 \%)$. The major isoprenoid quinone is $\mathrm{Q}-8$.

The type strain, Z $271^{\mathrm{T}}\left(=\mathrm{KMM} 6014^{\mathrm{T}}=\mathrm{CIP} 109923^{\mathrm{T}}\right)$, was isolated from the surface of leaves of Zostera marina grown in Troitza Bay, Gulf of Peter the Great, Pacific Ocean. The DNA G + C content of the type strain is $60.2 \mathrm{~mol} \%$.

\section{Acknowledgements}

The authors are thankful to Dr A. M. Lysenko for genetic analysis and to Dr Jang-Cheon Cho and Dr Lee Kiyoung for kindly providing the type strain of $G$. antarcticus. This study was partially supported by funds from the Australian Research Council (ARC) and by a grant from FEB RAS 'Study of biological diversity of marine heterotrophic bacteria'.

\section{References}

Azegami, K., Nishiyama, K., Watanabe, Y., Kadota, I., Ohuchi, A. \& Fukazawa, C. (1987). Pseudomonas plantarii sp. nov., the causal agent of rice seeding blight. Int J Syst Bacteriol 37, 144-152.

Bligh, E. G. \& Dyer, W. J. (1959). A rapid method of total lipid extraction and purification. Can J Biochem Physiol 37, 911-917.

Chevenet, F., Brun, C., Banuls, A. L., Jacq, B. \& Christen, R. (2006). TreeDyn: towards dynamic graphics and annotations for analyses of trees. BMC Bioinformatics 7, 439.
Christie, W. W. (1982). Lipid Analysis. Isolation, Separation, Identification and Structural Analysis of Lipids, p. 55. Pergamon Press.

De Ley, J., Cattoir, H. \& Reynaerts, A. (1970). The quantitative measurement of DNA hybridization from renaturation rates. Eur $J$ Biochem 12, 133-142.

Galtier, N., Gouy, M. \& Gautier, C. (1996). SEAVIEW and PHYLO_WIN, two graphic tools for sequence alignment and molecular phylogeny. Comput Appl Biosci 12, 543-548.

Gascuel, O. (1997). BIONJ: an improved version of the NJ algorithm based on a simple model of sequence data. Mol Biol Evol 14, 685-695.

Guindon, S. \& Gascuel, O. (2003). A simple, fast, and accurate algorithm to estimate large phylogenies by maximum likelihood. Syst Biol 52, 696-704.

Imhoff, J. F. 2005. Order I. Chromatiales ord. nov., pp. 1-3. In Bergey's Manual of Systematic Bacteriology, vol. 2 (The Proteobacteria), part B (The Gammaproteobacteria), 2nd edn. Edited by D. J. Brenner, N. R. Krieg, J. T. Staley \& G. M. Garrity. New York: Springer.

Ivanova, E. P., Kiprianova, E. A., Mikhailov, V. V., Levanova, F. G., Garagulya, A. G., Gorshkova, N. M., Yumoto, N. \& Yoshikawa, S. (1996). Characterization and identification of marine Alteromonas nigrifaciens strains and emendation of the description. Int J Syst Bacteriol 46, 223-228.

Ivanova, E. P., Kiprianova, E. A., Mikhailov, V. V., Levanova, G. F., Garagulya, A. D., Gorshkova, N. M., Vysotskii, M. V., Nicolau, D. V., Yumoto, Y. \& Yoshikawa, S. (1998). Phenotypic diversity of Pseudoalteromonas citrea from different marine habitats and emendation of the description. Int J Syst Bacteriol 48, 247-256.

Ivanova, E. P., Gorshkova, N. M., Sawabe, T., Zhukova, N. V., Hayashi, K., Kurilenko, V. V., Alexeeva, Y., Buljan, V., Nicolau, D. V. \& other authors (2004). Sulfitobacter delicatus sp. nov. and Sulfitobacter dubius sp. nov., respectively, from a starfish (Stellaster equestris) and sea grass (Zostera marina). Int J Syst Evol Microbiol 54, 475-480.

Ivanova, E. P., Bowman, J. P., Lysenko, A. M., Zhukova, N. V., Gorshkova, N. M., Kuznetsova, T. A., Kalinovskaya, N. L., Shevchenko, L. S. \& Mikhailov, V. V. (2005a). Erythrobacter vulgaris sp. nov., a novel organism isolated from the marine invertebrates. Syst Appl Microbiol 28, 123-130.

Ivanova, E. P., Bowman, J. P., Lysenko, A. M., Zhukova, N. V., Gorshkova, N. M., Sergeev, A. F. \& Mikhailov, V. V. (2005b). Alteromonas addita sp. nov. Int J Syst Evol Microbiol 55, 1065-1068.

Kurilenko, V. V., Ivanova, E. P. \& Mikhailov, V. V. (2007). Peculiarities of adhesion of epiphytic bacteria on leaves of the seagrass Zostera marina and on abiotic surfaces. Microbiology 76, 502-506.

Larkin, M. A., Blackshields, G., Brown, N. P., Chenna, R., McGettigan, P. A., McWilliam, H., Valentin, F., Wallace, I. M., Wilm, A. \& other authors (2007). ClustalW and ClustalX version 2. Bioinformatics 23, 2947-2948.

Lee, K., Lee, H. K., Choi, T.-H., Kim, K.-Y. \& Cho, J.-C. (2007). Granulosicoccaceae fam. nov., to include Granulosicoccus antarcticus gen. nov., sp. nov., a non-phototrophic, obligately aerobic chemoheterotroph in the order Chromatiales, isolated from Antarctic seawater. J Microbiol Biotechnol 17, 1483-1490.

Marmur, J. (1961). A procedure for the isolation of deoxyribonucleic acid from microorganisms. J Mol Biol 3, 208-218.

Marmur, J. \& Doty, P. (1962). Determination of the base composition of deoxyribonucleic acid from its thermal denaturation temperature. J Mol Biol 5, 109-118.

Smibert, R. M. \& Krieg, N. R. (1994). Phenotypic characterization. In Methods for General and Molecular Bacteriology, pp. 607-654. Edited by P. Gerhardt, R. G. E. Murray, W. A. Wood \& N. R. Krieg. Washington, DC: American Society for Microbiology. 
Wayne, L. G., Brenner, D. J., Colwell, R. R., Grimont, P. A. D., Kandler, O., Krichevsky, M. I., Moore, L. H., Moore, W. E. C., Murray,

R. G. E. \& other authors (1987). International Committee on
Systematic Bacteriology. Report of the ad hoc committee on reconciliation of approaches to bacterial systematics. Int J Syst Bacteriol 37, 463-464. 